\title{
Turcja w koncepcjach polskiego Sztabu Generalnego w okresie Konferencji Lozańskiej (1922-1923). Nieznane memorandum Tadeusza Schaetzla
}

Zarys treści: W artykule przedstawiony został memoriał Tadeusza Schaetzla z 26 grudnia 1922 r., pisany jako analiza pierwszej części obrad konferencji w Lozannie. Mjr Schaetzel przygotował go dla Sztabu Generalnego, powróciwszy do Warszawy z Lozanny, gdzie obserwował obrady konferencji pokojowej. Tekst dokumentu przepełniony jest nadziejami na pozyskanie w przyszłości Turcji dla antysowieckiej polityki II RP.

Outline of content: The article presents Tadeusz Schaetzel's memorandum from 26 December 1922, containing his analysis of the first round of negotiations at the Lausanne Conference. It was prepared on request of the General Staff, following Schaetzel's return from Lausanne, where he assumed the duties of observer at the peace conference. The document proves strong hopes for a future involvement of Turkey in the anti-Soviet policies of the Second Polish Republic.

Słowa kluczowe: II Rzeczpospolita, Turcja, Mustafa Kemal Atatürk, Tadeusz Schatzel, polsko-tureckie stosunki wojskowe i polityczne w okresie międzywojennym, konferencja pokojowa w Lozannie

Keywords: second Republic of Poland, Turkey, Mustafa Kemal Atatürk, Tadeusz Schatzel, PolishTurkish military and political relations in the interwar period, Conference of Lausanne

Konferencja pokojowa w Lozannie (listopad 1922-czerwiec 1923 r.) stanowiła jedno z najważniejszych wydarzeń politycznych w procesie kształtowania terytorialnego ładu dla Europy po Wielkiej Wojnie. Po zakończonej przytłaczającym zwycięstwem Turcji wojnie z Grecją (wspieraną przez mocarstwa sprzymierzone) przygotowano i podpisano nowy i ostateczny traktat pokojowy z Turcją ${ }^{1}$. Warunki były negocjowane w sposób swobodny. Turcja zdołała zbrojnie przekreślić godzące w jej niepodległość postanowienia pierwotnego traktatu pokojowego, podpisanego

1 Wojna toczyła się w latach 1921-1922. 
z rządem sułtańskim w Sèvres 10 sierpnia 1920 r., który opracowano po kapitulacji sułtańskiej Turcji 30 października 1918 r., na Konferencji Pokojowej w Paryżu².

Główną rolę podczas obrad odgrywała dyplomacja brytyjska, a delegacji Zjednoczonego Królestwa przewodniczył Lord Curzon. Był to ostatni akord jego działalności politycznej zakończonej śmiercią w roku 1925. Francja usiłowała osiągnąć możliwie korzystny dla siebie podział spuścizny terytorialnej imperium osmańskiego, ale podział ten wypadł jednak generalnie na korzyść Wielkiej Brytanii. Trzecim mocarstwem europejskim pozostawały Włochy, a konferencja zebrała się zaledwie parę tygodni po zdobyciu władzy przez faszystów. Stany Zjednoczone, które nie wypowiedziały wojny sułtańskiej Turcji (jako aliantowi Niemiec), nie miały tytułu prawnego do takiego udziału i wysłały na konferencję tylko swego obserwatora. Zaproszono za to rząd Rosji Sowieckiej (od grudnia 1922 r. - ZSRR).

Delegacji tureckiej przewodniczył Iszmet Pasza - który później jako prezydent Republiki przyjął nazwisko Ismet Inönü${ }^{3}$. Jak to ujął wytrawny znawca problemów Turcji Bernard Lewis w znanej książce Narodziny nowoczesnej Turcji, „bitwa militarna była wygrana"4. Ale nie oznaczało to, że rokowania są wygrane. Delegacja turecka kierowała się zasadami przyjętego przez republikańskie Zgromadzenie Narodowe „Paktu Narodowego”. Miano instrukcję, by zerwać rozmowy, gdyby zażądano systemu kapitulacji ${ }^{5}$. Sprawa cieśnin również została postawiona przez rząd turecki jednoznacznie. Żądano pełnej kontroli Turcji nad nimi i zamknięcia morza dla flot wojennych państw nie leżących nad Morzem Czarnym. Turcję wydatnie wsparli Sowieci. Konflikt o Mosul z Wielką Brytanią oraz o Aleksandrettę z Francją stanowiły najpoważniejsze problemy terytorialne, gdyż rząd nowej Turcji pogodził się z utratą posiadłości imperium osmańskiego, koncentrując się na walce o niezawisłe państwo w Anatolii. Powstał wielce skomplikowany problem wymiany ludności z Grecją, co załatwiono ostatecznie podpisaniem konwencji lozańskiej. Zniesienie systemu kapitulacji było pierwszym postulatem Turcji, która chciała wyjść z wojny w pełni suwerenna. Występował problem kredytów osmańskich, gdyż rząd nowej Turcji nie chciał honorować tych zobowiązań, chociaż ostatecznie pogodził się z koniecznością ustępstw na rzecz aliantów. Sprawa redukcji sił zbrojnych Turcji (ograniczonych traktatem w Sevres do 50 tys.) nie była w ogóle przedmiotem obrad. Wspomniane powyżej trudności spiętrzyły się i przyniosły kryzys konferen-

2 Traktat w Sevres pozostawiał Turcji tylko Anatolię północną i środkową oraz Stambuł wraz z otaczającym go rejonem. Trację Wschodnią dostała Grecja. Syria i Liban - jako mandat przypadły Francji. Irak był mandatem W. Brytanii. Kurdystan miał dostać autonomię. Powstać miało na wschodzie Anatolii państwo armeńskie. Armia turecka liczyłaby 50 tys. żołnierzy na stopie pokojowej. Traktat w Sèvres nie był ratyfikowany i został uznany za akt niebyły.

3 Publikację wówczas znanych dokumentów Konferencji Lozańskiej przygotował włoski historyk Amedeo Giannini: Documenti per la pace orientale, 1915-1932, ed. A. Giannini, Roma 1933. Tureccy historycy wydali korespondencję dyplomatyczną delegacji z rządem w Ankarze: Telegrammes de Lusanne. Documents diplomatiques sur la Conférence de la Paix de Lausanne, vol. I, Ankara 1990.

4 B. Lewis, Narodziny nowoczesnej Turcji, przekł. K. Dorosz, Warszawa 1972, s. 305.

5 Zob. D. Chmielowska, Polsko-tureckie stosunki dyplomatyczne w okresie międzywojennym, Warszawa 2006, s. 177. 
cji między styczniem a kwietniem 1923 r., lecz obrady wznowiono i ostatecznie po trwających osiem miesięcy obradach podpisano Traktat pokoju z Turcją 24 lipca $1923 \mathrm{roku}^{6}$. Zawarto też Konwencję o Cieśninach, zawierającą zgodę Turcji na ich demilitaryzację. Konwencja o wymianie ludności z Grecją doszła do skutku już wcześniej - 30 stycznia 1923 r., a była to pierwsza międzynarodowa umowa przewidująca przesiedlanie ludzi na wielką skalę w historii powszechnej ${ }^{7}$.

Położenie i problemy nowej Turcji nie były w polskiej myśli politycznej problemem centralnym ${ }^{8}$. Obrady lozańskiej obserwowano jednak w Warszawie z dużą uwagą - tak ze strony dyplomacji jak i wywiadu. Był ku temu jeden ważny powód, zawarty w potrzebie rozeznania jakie będzie stanowisko nowej Turcji w stosunkach międzynarodowych i jej polityka wobec państwa Sowietów. Mając świadomość, że nowa Turcja pozostaje ważnym obiektem zainteresowania polityki polskiej, marszałek Piłsudski osobiście interesował się żywo rokowaniami w Szwajcarii i nakazał sobie przedstawiać regularnie gromadzone informacje na ten temat ${ }^{9}$. Niewątpliwie też prestiż i respekt wobec Turcji w Europie - które wystąpiły jako pokłosie jej zwycięskiej wojny z Grecją - udzielał się także polskiemu przywódcy. Dochodziło też zapewne przekonanie o poparciu tego państwa dla antyrosyjskich koncepcji politycznych polskich $\mathrm{z}$ doby porozbiorowej ${ }^{10}$.

Podkreślmy w tym miejscu, iż stosunki polsko-tureckie uważano w Warszawie za strategicznie ważne w myśl niepisanej doktryny o potrzebie koordynacji polityki sąsiadów ZSRR. Należy odnotować, iż w styczniu 1922 r. szef Sztabu Generalnego gen. Władysław Sikorski dał wyraz przekonaniu, że Turcja swoją polityką zagraniczną wykazuje „tendencje rozwojowe w kierunku opanowania Kaukazu w myśli politycznej tureckiej istnieją i to daje możność uzgodnienia polityki naszej z polityką turecką w perspektywie dłuższego okresu czasu" ${ }^{11}$. Na początku 1918 r., jak wiadomo, na

6 Literatura na ten temat jest znaczna: zob. H. Nicolson, Curzon: the last phase 1919-1925. A Study in postwar diplomacy, London 1934; J. Nevakivi, Britain, France and the Arab Middle East: 1914-1920, London 1969. W historiografii polskiej - oprócz wspomnianej monografii Chmielowskiej - zob. H. Batowski, Między dwiema wojnami 1919-1939. Zarys historii dyplomatycznej, Kraków 1988, rozdz. V, s. 67-77. Problematykę budowy międzynarodowej pozycji nowej Turcji ujmują: Tomasz Wituch, w swej podstawowej monografii: Tureckie przemiany. Dzieje Turcji 1878-1923, Warszawa 1980, oraz Dariusz Kołodziejczyk, Turcja, Warszawa 2010. Ogólnie zainteresowanie historiografii polskiej problematyką polityki tureckiej pozostaje stosunkowo małe, a bariera językowa w dostępie do źródeł z tego kraju odgrywa tu sporą rolę.

$7 \mathrm{Na}$ dużo mniejszą skalę „transfer ludności” przewidywał już układ bukaresztański kończący II wojnę bałkańską (1913).

8 Zob. np. szkic Konrada Libickiego, Kaukaz, „Wschód Polski”, nr 5, 1920, s. 16-26 albo publicystykę pisma „Przymierze” (1920-1921), które patronowało tzw. Związkowi Zbliżenia Narodów Odrodzonych (zob. M. Kornat, U źródeł idei prometejskiej. Związek Zbliżenia Narodów Odrodzonych (1921-1923), „Nowy Prometeusz”, nr 2, lipiec 2012, s. 161-184). W r. 1930 pisarz polityczny Leon Kozłowski zebrał swą publicystykę w tomie Półksiężyc i gwiazda czerwona. Wybór pism, Wilno 1930.

9 D. Chmielowska, op. cit., s. 174.

10 Mamy tu na myśli przede wszystkim dyplomację Hotelu Lambert Adama Jerzego Czartoryskiego.

11 Dokumenty z dziejów polskiej polityki zagranicznej 1918-1939, t. 1: 1918-1932, oprac. T. Jędruszczak i M. Nowak-Kiełbikowa, Warszawa 1989, s. 189. Referat ów Sikorski przedłożył na podstawie opracowania szefa II Oddziału płk. Ignacego Matuszewskiego. 
Kaukaz wkroczyła armia turecka (a za nią Niemcy). Dało to asumpt do jakże ważnej z punktu widzenia interesów polskich emancypacji politycznej narodów tego regionu (Gruzji i Azerbejdżanu), a wyzwolona Gruzja zawarła pokój z Turcją ${ }^{12}$. Dla polskich kół wojskowych wydawało się nieuchronne, że nowe państwo tureckie pójdzie przeciw Rosji, podnosząc doktrynę wyzwolenia narodów ujarzmionych w imperium sowieckim - przede wszystkim Kaukazu, w myśl własnego pobratymstwa z nimi.

Obserwatorem polskim wysłanym na Konferencję Lozańską był major Sztabu Generalnego Tadeusz Schaetzel. Wszedł on w kontakt z gen. Iszmetem za pośrednictwem lidera krymskich Tatarów Dżafera Seydameta, polityka, który reprezentował propolskie tendencje i w 1920 r. zgłosił ideę autonomizacji Krymu poprzez powierzenie nad tym terytorium mandatu Polsce przez Ligę Narodów (w myśl jej Statutu).

Schaetzel stał się niewątpliwie jednym z najwybitniejszych rzeczników prometeizmu w polskiej armii. Urodzony 12 marca 1891 r. w Brzeżanach (w Galicji Wschodniej), studia wyższe rozpoczął na Politechnice Lwowskiej, a ukończył w Grazu. Służył w Związku Walki Czynnej oraz uczestniczył w pracach Związku Strzeleckiego. Wstąpił do Legionów Piłsudskiego, a po „kryzysie przysięgowym” 1917 r. wcielony został przymusowo do armii austriackiej, ale po dezercji w rok później zdołał przedostać się do ogarniętej rewolucją Rosji, tam zaś wstąpił do konspiracyjnej Polskiej Organizacji Wojskowej. Po odzyskaniu niepodległości przydzielony został do Naczelnego Dowództwa, rozpoczął pracę w wywiadzie. W czasie bitew pod Warszawą i nad Niemnem pełnił funkcję szefa Oddziału II w Sztabie Naczelnego Wodza. Po zakończeniu działań wojennych kierował Wydziałem Ewidencji II Oddziale ${ }^{13}$.

Konferencja Lozańska dała dyplomacji polskiej asumpt do rozpoczęcia rozmów dwustronnych z Turcją na temat utrwalenia stosunków wzajemnych. 18 maja 1923 r. rozpoczęto takie negocjacje w Lozannie ${ }^{14}$. Kierował nimi ze strony polskiej Jan Modzelewski, poseł RP przy Rządzie Konfederacji Szwajcarskiej, dyplomata związany z Komitetem Narodowym Polskim Dmowskiego. Rozmowy przyniosły trzy umowy: Traktat o wieczystej przyjaźni, konwencję handlową i konwencję osiedleńczą. Wszystkie podpisano 23 lipca 1923 r., w przededniu zawarcia Traktatu Lozańskiego. Traktat o wieczystej przyjaźni nie był niestety sojuszem ${ }^{15}$. Konwencja handlowa miała jednak istotne znaczenie, gdyż zapewniała stronie polskiej wolny tranzyt broni i zaopatrzenia armii w wypadku wojny. To, że Polacy podjęli rozmowy z Turkami, nie konsultując tego faktu z Francją, uznano w Paryżu za sprzeczne z postanowieniami sojuszu z 19 lutego 1921 roku$^{16}$.

12 Szerzej o tych sprawach zob. W. Materski, Powstanie i upadek państw narodowych na Zakaukaziu (1918-1925), [w:] Państwa narodowe Europy Środkowo-Wschodniej w XX wieku, red. W. Balcerak, Łowicz-Warszawa 2000, s. 147-158.

13 Biogram Schaetzla (pióra Piotra Staweckiego) podaje PSB, t. 35, 1994, s. 393-395.

14 D. Chmielowska, op. cit., s. 186.

15 Ibidem, s. 172 i n.

16 Raport ambasadora w Warszawie Hectora de Panafieu z Panafieu z 20 czerwca 1923 dla premiera i ministra spraw zagranicznych Poincarégo, Archives du Ministere des Affaires Etrangeres (Paris), Europe 1918-1940, Pologne, vol. 74. 
Publikowany poniżej dokument wydaje się istotnym materiałem do analizy polskich koncepcji politycznych związanych z nową kemalistowską Turcją. Memoriał z 26 grudnia 1922 r., pisany jako analiza pierwszej części obrad, przygotował dla Sztabu Generalnego mjr Schaetzel, powróciwszy do Warszawy z Lozanny, gdzie obserwował obrady konferencji pokojowej. Tekst dokumentu przepełniony jest niewątpliwie nadziejami na pozyskanie Turcji dla polityki antysowieckiej w przyszłości. „Angora nie może zapomnieć również o 25 milionach mahometan pod panowaniem rosyjskim, którzy w Turcji widzą ostoję ruchu narodowego i religijnego" - to stwierdzenie, które mówi wiele. Autor, kontynuując swe rozważania, dochodził też do wniosku, iż bolszewizm nie zdoła zbudować skutecznie nowego imperium na gruzach caratu. „Propaganda uświadomienia narodowego jest jednak równocześnie podgrzebywaniem wielkiej i niepodzielnej Rosji, która jest konieczna dla realizacji całości zamierzeń bolszewickich. W tej sprzeczności tkwi tragizm wielkich placów wschodnich komunizmu. Na terenie najskuteczniejszej swej działalności podkopują własny byt. Z drogi tej jednak ustąpić nie mogą" - dowodził polski oficer-dyplomata.

Co do przyszłej polityki tureckiej, Schaetzel nie przypuszczał, by stosunki turecko-sowieckie ukształtowały się przyjaźnie. „Po likwidacji frontu anatolijskiego - pisał - przestała Turcja odgrywać dla Rosji sow[ieckiej] rolę ważnego sprzymierzeńca w polityce europejskiej. Możliwość nawiązania przez Turcję stosunków dyplomatycznych z państwami zachodnimi, a przede wszystkim z Polską i Rumunią, oraz jej ewentualne wstąpienie do Ligi Narodów, rolę dotychczasową pod tym względem poważnie zmieniają. Istotne kryterium dla stosunku Rosji sowieckiej względem Turcji stanowi obecnie jej rola w świecie wschodnim. Turcja jako sojusznik państwowej polityki rosyjskiej nie ma ani części tego znaczenia, jakie mogłaby mieć jako sojusznik we wschodnim programie bolszewickim. O tę Turcję walczy jeszcze rząd sowiecki”.

Walka ta okazała się w jakiejś mierze skuteczna. Jak bowiem pokazać miała historia dyplomacji, polityka życzliwej współpracy z Sowietami będzie dla Turcji zasadniczym programem polityki zagranicznej aż do roku 1939. Poparcie, jakie ujawniła dyplomacja sowiecka dla rządu nowego państwa tureckiego, położyło podwaliny pod ten stan rzeczy ${ }^{17}$. Ale był też drugi ważny powód tego stanu rzeczy - tj. brak rewizjonistycznych zamysłów republikańskiej Turcji. Jak napisze B. Lewis, „wyrzekając się wszelkich zagranicznych ambicji, wszelkich ideologii pantureckich, panosmańskich i panmuzułmańskich, ograniczył świadomie swe działania i aspiracje do narodowego terytorium Turcji - takiego, jak określały go traktaty"18.

Zachowawcza polityka Turcji wobec ZSRR sprawiła, iż w jednym z dokumentów II Oddziału padło nawet stwierdzenie o „wrogim” stosunku Turcji do emi-

17 Według doniesień polskiej dyplomacji, Turcy mieli nawet zwrócić się o pomoc finansową do Sowietów - o kredyt i 200 tys. ludzi do walki (szyfr z MSZ do ambasady w Londynie z 14 lutego 1923. Instytut Sikorskiego (Londyn), Ambasada Londyn, sygn. A.12.53/46).

18 B. Lewis, op. cit., s. 305-306. 
gracji prometejskiej ${ }^{19} .17$ grudnia 1925 r. rządy w Ankarze i Moskwie podpisały traktat o przyjaźni ${ }^{20}$. W memorandum MSZ z 1934 r. spotykamy stwierdzenie: „Na każdym kroku starały się [władze sowieckie] przy tym przekonywać Turcję, że zrezygnowały $\mathrm{z}$ dawnych rosyjskich dążeń do opanowania Konstantynopola wraz z cieśninami, w zamian za to miarodajne sfery tureckie wyrzekły się, przynajmniej oficjalnie, popierania ruchu panturańskiego mającego na celu zjednoczenie wszystkich ludów pochodzenia turko-tatarskiego, zamieszkujących Rosję, Turcję, Chiny i Persję"21.

Mimo tak wyraźnego rozejścia się dróg między Warszawą a Ankarą starania polskie, by na terenie Turcji rozpocząć budowę międzynarodowego ruchu na rzecz walki z imperium sowieckim, nie były jednak całkiem bezowocne. Na terytorium Turcji w rezultacie misji Romana Knolla (1924-1925) doszło do zarysowania podstaw współdziałania emigracji narodów prometejskich i polskiej służby zagranicznej22. W grudniu 1924 r. Tadeusz Schaetzel został przez polski Sztab Generalny skierowany do Ankary jako attaché wojskowy. Pracował na tym stanowisku do lata 1926 r., kiedy zostanie odwołany do pracy w centrali, w związku z przewrotem $\mathrm{w}$ Polsce. W czasie swej misji nawiązał podstawowe kontakty z emigracją „narodów prometejskich”, głównie kaukaskich, co dało na przyszłość podstawy dla ruchu prometejskiego ${ }^{23}$. Jak można wnosić, władze polskie skłaniały się do uznania, że do konfliktu z sowiecką Rosją doprowadzi ekspansja turecka na Kaukaz, co jednak nie znajdzie potwierdzenia.

Schaeztel, opuściwszy służbę w wywiadzie i przechodząc do pracy w MSZ (jako naczelnik Wydziału Wschodniego), będzie powracał do koncepcji prometejskiej - m.in w wystąpieniu Racja stanu Polski na Wschodzie wygłoszonym w redakcji miesięcznika piłsudczyków „Droga” w Warszawie ${ }^{24}$.

Publikowany dokument przechowuje Rosyjskie Państwowe Archiwum Wojskowe (RGWA) w Moskwie (fond 308, NDWP), op. 12, t. 96 k. 1-25. Publikujemy jego tekst $\mathrm{z}$ przekonaniem, iż wydaje się on interesującym, a nieznanym przyczynkiem źródłowym do historii stosunków polsko-tureckich i dziejów dyplomacji polskiej, przede wszystkim zaś koncepcji polityki wschodniej.

19 Zob. S. Wroński, Współdziałanie rządu polskiego z emigracyjnymi organizacjami antyradzieckimi w latach 1918-1939, „ZZ Dziejów Stosunków Polsko-Radzieckich. Studia i Materiały”, t. III, 1968, s. 277.

20 Zob. więcej: Ch. W. Hostler, Turkism and the Soviets. The Turks of the World and their Political Objectives, London 1957.

21 Tak w memorandum polskiego MSZ z 1934 r. - Dokument z 1934 r. o zasadach polskiej polityki zagranicznej w Europie Środkowej i na Bałkanach, oprac. J. Tomaszewski, „Przegląd Historyczny”, t. 76 , z. 4,1985 , s. 807.

22 Szczegółowo na ten temat: H. Bartoszewicz, Misja Romana Knolla w Ankarze 1923-1924, „Studia z Dziejów Rosji i Europy Środkowo-Wschodniej”, t. 36, 2001, s. 109-126.

23 Analiza koncepcji Piłsudskiego wobec Turcji Kumala - zob. M. Sokolnicki, Polityka Piłsudskiego a Turcja, „Niepodległość”, t. VI, 1958, s. 5-22.

24 Tekst został opublikowany pod pseudonimem „Tomasz Krymski” [w:] Pod znakiem odpowiedzialności i pracy. Dziesięć wieczorów, Droga, red. A. Skwarczyński, Warszawa 1933 (przedrukowany w piśmie: „Niepodległość” 1972, nr 8, s. 225-249). 
Warszawa, 26 grudnia $1922 \mathrm{r}$.

Raport z Konferencji Pokojowej w Lozannie przebieg do dnia 26 grudnia

Charakter Konferencji. Konferencja Lozańska ma być ostatnim aktem wojny turecko-greckiej dla ustalenia nowego układu stosunków na Bliskim Wschodzie ${ }^{25}$. Ma więc nadać formę prawną rewizji Traktatu w Sèvres i Neuilly ${ }^{26}$ rozpoczętej przez zbrojną akcję Mustafy Kemala ${ }^{27}$, zarówno jak być rozrachunkiem między Anglią a Francją tych strat i zysków, z którymi obaj Alianci przystępują do likwidacji sporu przez siebie wyzyskiwanego.

Front w Anatolii był terenem walki nacjonalistów tureckich o niepodległość państwową przeciw dążeniom greckiego maksymalizmu. Na froncie tym rozgrywała się zarazem ukryta walka Anglii i Francji, które przy pomocy obcych rąk dokonywały części wzajemnych rozrachunków.

Za Turcją Angorską stanął w jej walce cały rozbudzający się świat islamu, który widział w Kemalu oswobodziciela głowy Kościoła mahometańskiego i uosobienie wyzwoleńczego ruchu przeciw okupantom, stała Rosja sowiecka z ogromnym aparatem propagandy nacjonalistycznej na Wschodzie oraz pomocą udzieloną i przyrzekaną,stała wreszcie Francja, która swą pomoc materialną i wiekowe stanowisko eskontowała dla zabezpieczenia stanu posiadania oraz dla szachowania Anglii na terenie jej interesów tak, jak sama odczuwać musiała nieprzychylny jej nacisk w sprawach europejskich.

Grecję pchał do walki nakaz angielski i miraże rekonstrukcji imperium bizantyńskiego.

Każdy z tych wielu czynników, które bezpośrednio lub pośrednio brały udział w wojnie turecko-greckiej, ma swój wpływ przy jej likwidacji. Ilość zagadnień, które mają być rozstrzygane w Lozannie, zwiększyła się przez udział w Konferencji Państw, które w akcję wojenną wmieszane nie były, ale których obecność w Lozannie była nieunikniona. Bardziej jednak komplikuje Konferencję fakt, że dokoła zagadnienia Bliskiego Wschodu skupiają się zasadnicze problemy życia międzynarodowego, o które musi się potrącać dotykając spraw tego terenu.

Tło i kulisy Konferencji. Bliski i dalszy Wschód jest w obecnej epoce terenem, na którym moralne pierwiastki społecznego życia rozwijają się w sposób najżywszy. Przez tereny te przechodzi silna fala narodowej i religijnej świadomości budzącej

25 Konferencja Lozańska rozpoczęła się 21 listopada 1922, a zakończyła 23 lipca 1923 r.

26 Traktat pokojowy zwarty był z Bułgarią 27 listopada 1919 r. w Neuilly-sur-Seine. Utraciła ona dostęp do Morza Egejskiego. Trację Zachodnią dostała Grecja. Dobrudża Południowa przeszła do Rumunii. Armię zredukowano do 25 tys. żołnierzy.

27 Kemal Mustafa (Atatürk), 1881-1938, generał, twórca i przywódca republikańskiej Tucji, prezydent Republiki w latach 1923-1938. 
w ludach dotąd uśpionych pęd do walki o samodzielność polityczną i niezależność gospodarczą. Stan zapewniający Mocarstwom zachodnim uprzywilejowaną sytuację zostaje zachwiany. Nie wystarcza 22 paragraf Traktatu o Lidze Narodów, który określa rolę Wielkich Mocarstw na Wschodzie tylko jako chwilowych mandatariuszy mających ułatwić niedojrzałym społecznościom utrzymanie się na powierzchni skomplikowanego obecnie życia międzynarodowego. Mandaty zostały przez te narody zrozumiane zgodnie $\mathrm{z}$ ich treścią istotną, jako ukryta forma poparcia siłą zbrojną politycznych i gospodarczych interesów Wielkich Mocarstw.

Walka o zdobycie nowych praw z jednej strony i utrzymanie stanu posiadania z drugiej zarysowuje się na Konferencji w sposób bardzo wyraźny.

Ruch nacjonalistów tureckich sprowadza się do zdecydowanej obrony niepodległości państwowej. Zasada ta jest punktem wyjścia wszystkich postulatów delegacji tureckiej oraz jej polityki zarówno dotyczących zagadnień wewnętrznych, jak i roli Turcji w islamie. Wyraża się ona przede wszystkim w kategorycznej tendencji do zniesienia wszelkich dotychczasowych form prawnych, które Turcję stawiają poza nawiasem państw równouprawnionych, oraz $\mathrm{w}$ obronie przeciw wszystkim klauzulom Traktatu, które by faktycznie lub pozornie naruszały jej suwerenność.

Te same tendencje sprowadziły do Lozanny szereg delegacji z terytoriów objętych okupacją Wielkich Mocarstw (Syria, Palestyna, Egipt), które domagają się uznania niepodległości i zniesienia okupacji wojskowej.

Pojawiły się również w kuluarach Konferencji przedstawicielstwa Rządów i organizacji muzułmanów rosyjskich, które drogą dyplomatyczną lub z bronią w ręku zwalczają panowanie bolszewickie.

Charakterystyczne na tym tle jest wystąpienie Ambasadora Childa ${ }^{28}$, reprezentanta St. Zjednoczonych, w obronie zasady „otwartych drzwi”. Jest ono bowiem wyrazem bardziej nowoczesnej metody podboju, metody okupacji ekonomicznej bez poparcia siły zbrojnej. Przyszłość bliska może okazać słuszność tej tezy.

Drugą sprawą nie związaną bezpośrednio z Konferencją, która jednak o Konferencję zatrąca, są wielkie zagadnienia religijne. O progi Konferencji obijają się fale wielkich tendencji Kościołów europejskich. Każda organizacja kościelna przejawia się jako samodzielny czynnik życia międzynarodowego albo jako jeden ze środków państwowej polityki w stosunkach zewnętrznych. Tę drugą rolę spełnia przede wszystkim Kościół anglikański, który wykazuje ostatnio ogromną aktywność. Jego akcja polityczna zarysowała się podobno w sposób jaskrawy przy naszych wyborach na Kresach. W kwestii Bliskiego Wschodu wyraziła się działalność głównego szermierza polityki Kościoła anglikańskiego, arcybiskupa Canterbury ${ }^{29}$, niezwykle żywą propagandą prowadzoną w Ameryce przeciw światowi mahometańskiemu. Ten sam charakter miało wystąpienie

28 Richard W. Child, dyplomata amerykański miał status obserwatora Konferencji Lozańskiej, gdyż Stany Zjednoczone nie były jej stroną, nie będąc w ogóle w stanie wojny z Turcją.

29 Arcybiskupem Canterbury (i tym samym prymasem Anglii) i zwierzchnikiem Kościoła Anglii był Randall Davidson, a urząd ten sprawował w latach 1903-1928. 
antyfrancuskie tegoż arcybiskupa na nabożeństwie na otwarciu tegorocznego Zgromadzenia Ligi Narodów.

Ideą obecnych kierowników Kościoła anglikańskiego jest zjednoczenie wszystkich Kościołów niekatolickich z prawosławnym. Konferencje dla zmodyfikowania dogmatów stanowią pierwszy krok do tej Unii. Belgrad i Konstantynopol są ważnymi ośrodkami prac przygotowawczych.

Na tym tle specjalnego znaczenia nabiera walka, która się toczy na Konferencji Lozańskiej o Patriarchat Wschodni w Konstantynopolu. Zgodnie z przywilejem nadanym przez Sułtana Mehmeda II po zajęciu Konstantynopola ${ }^{30}$ był Patriarchat Konstantynopolitański członkiem „Wielkiego Dywanu” i miał prawo wyłącznej jurysdykcji nad obywatelami tureckimi wyznania wschodniego. Kościół wschodni wyznacza również patriarsze Konstantynopola jedno z najwyższych stanowisk w hierarchii kościelnej. W ten sposób wpływ dygnitarza Kościoła wschodniego na wewnętrzne życie Turcji był zawsze b. silny. Arcybiskup Meletios IV ${ }^{31}$ szczególnie szkodliwą dla Państwa odegrał rolę w walkach religijnych ostatnich lat. Nic też dziwnego, że Turcy, przystępując do reformy wewnętrznych stosunków, a przede wszystkim do radykalnego zlikwidowania kwestii mniejszości, które uważają za największą groźbę wewnętrzną i za precedens do obcych ingerencji, w pierwszej linii postanowili usunąć wrogiego patriarchę wraz z całą Radą Patriarchalną i stworzyć Kościół autokefaliczny. Na głowę tego Kościoła miał być powołany Turek wyznania wschodniego, duchowny z Angory Papa Effendi ${ }^{32}$. Wyrzucenie Meletiosa z Konstantynopola spotkało się z gwałtownym oporem ze strony angielskiej i jest dotąd przedmiotem ostrej polemiki. Francuski delegat de la Croix ${ }^{33}$ zgłosił kompromisowy wniosek, aby zachować instytucję patriarchatu w Konstantynopolu, odbierając patriarsze jego władzę i uprawnienia świeckie. Wniosek ten miał szanse przejścia.

Przez Konstantynopol i Belgrad idą i ze strony Kościoła katolickiego tendencje unii z prawosławiem.

Słowa Kardynała Gaspariego, że świat muzułmański i katolicki, które jak ogień i woda są żywiołami zupełnie różnymi i nigdy sobie przeszkadzać nie mogą, świadczą o możliwości dobrych stosunków między obu tymi Kościołami. Obecność w Lozannie nuncjusza papieskiego $\mathrm{z}$ Berna $^{34}$ i żywe jego zainteresowanie Konferencją pozostaje $\mathrm{w}$ łączności $\mathrm{z}$ tymi zagadnieniami.

Nie pozostają biernymi wobec wypadków na Bliskim Wschodzie również Żydzi. W świecie Syjonu bezpośrednio zainteresowanym w rozwoju stosunków na tere-

30 Miało to miejsce w maju $1453 \mathrm{r}$.

31 Meletios IV (1871-1935), patriarcha ekumeniczny Konstantynopola od listopada 1921 do września $1923 \mathrm{r}$.

32 Delacroix. Victor Delacroix (+), dyplomata francuski, radca ambasady w Bernie, członek delegacji francuskiej na konferencję w Lozannie, późniejszy poseł w Pradze.

33 Kard. Pietro Gasparri (1852-1934), sekretarz stanu Stolicy Apostolskiej w latach 1915-1930, pod rządami papieży Benedykta XV i Piusa XI.

34 Był nim mons. Luigi Maglione (1877-1944), późniejszy nuncjusz w Paryżu i sekretarz stanu w latach 1939-1944. 
nach objętych mandatami angielskimi, nastąpił w ostatnich czasach rozłam na tle stanowiska względem Anglii. Rola żywiołu dominującego, którą wyznaczyli Anglicy Żydom w Palestynie, zwróciła przeciw Imperium Brytyjskiemu nie tylko mahometańską i chrześcijańską ludność, ale i uprzywilejowaną mniejszość, którą użyto dla tego ryzykownego zadania. Część Syjonu stanęła już do walki z Imperium Brytyjskim razem z islamem. Wybitny udział wielkiego rabina Konstantynopola Szahib Basłama w delegacji tureckiej i uroczysty obiad wydany dla Ismeta Baszy ${ }^{35}$ przez W. Rabina Genewy są objawami znamiennymi.

Na terenie Bliskiego Wschodu schodzą się i krzyżują wielkie idee zachodnich organizacji kościelnych. Schodzą się w obliczu świata muzułmańskiego dla walki z nim lub dla przymierza.

Poza ramy Konferencji pokojowej wykracza również kwestia cieśnin. Jakkolwiek zagadnienie to zawarte jest w programie Konferencji i stanowi jeden z głównych tematów obrad, należy je rozpatrywać również z punktu widzenia ogólnego. Jest to bowiem pierwsza próba rozwiązania w płaszczyźnie i na zasadach międzynarodowych kwestii, które dotąd były rozstrzygane w płaszczyźnie przywilejów i uprawnień pojedynczych Mocarstw (statut cieśnin tureckich i wynikający stąd stan sił zbrojnych na Morzu Czarnym ujęty będzie w specjalnym raporcie po decyzjach ostatecznych, które jeszcze nie zapadły). Fakt, że W. Brytania, zmuszona warunkami, wysunęła $\mathrm{w}$ sprawie cieśnin tureckich zasady stanowiące b. niebezpieczny precedens dla uprzywilejowanego stanowiska, jakie posiada, władając Suezem, Gibraltarem i innymi cieśninami, wywołał silne echo, zarówno w świecie jej wrogów, jak sprzymierzeńców. Podniosła to półoficjalna prasa francuska, powtórzył Cziczerin ${ }^{36}$ w Lozannie, podkreślają głośno przede wszystkim delegacje egipskie. Z uwagą śledzą ten fakt również Włochy, stale drażnione w ambicjach mocarstwowych, które marzą o przodującym stanowisku w związku śródziemnomorskim, którego samodzielność uniemożliwiona jest, jak długo Anglia włada wszystkimi cieśninami tego morza. Włochy ograniczają się na razie do lansowania koncepcji „jedności śródziemnomorskiej" i jednania dla niej sprzymierzeńców przede wszystkim w Turcji i Egipcie.

Koncepcja ta dziś jeszcze nierealna, jak nieaktualna jest rewizja obecnego stanu wszystkich cieśnin; leży jednakże na drodze rozwoju wypadków.

Państwa biorące udział w Konferencji. Scharakteryzowany na początku raportu układu dwu obozów, których wyrazem były walki na froncie anatolskim, nie utrzymał się na Konferencji. Od pierwszej zaraz chwili wykazał przebieg obrad niestałość ugrupowań wywołaną niezgodnością interesów i dążeń. W tym stanie najsłuszniej będzie rozpatrywać stanowisko i rolę każdego z Państw z osobna.

ANGLIA. Weszła na Konferencję z ujemnym dorobkiem: klęską Greków, których pchnęła do wojny. Wojska alianckie, a z nimi prestige mocarstwowy, przechodziły

35 Iszmet Pasza (Ismet Inonü), 1884-1973, generał i polityk turecki. Minister spraw zagranicznych, premier oraz prezydent Republiki w latach 1938-1950.

36 Georgij Cziczerin (1872-1936), ludowy komisarz spraw zagranicznych Rosji Sowieckiej (19171922), a następnie ZSRR (1922-1930). 
pod grozą ataków kemalistów chwile krytyczne, zanim angielskie siły w cieśninach nie zostały pokaźnie zasilone. Mudamia ${ }^{37}$ zastała Anglików już pewnych siebie, ale skłonnych do uległości wobec zasadniczych postulatów terytorialnych Turcji. Dla panowania nad Konferencją Lozańską potrzebowała Anglia swobody działania w sprawach zachodnich granic Turcji i wolnej ręki ze strony Francji w sprawie całości zagadnień Bliskiego Wschodu. Do zrealizowania pierwszego celu służyć miały Państwa Bałkańskie. Za pośrednictwem Venizelossa ${ }^{38}$, najindywidualniejszej osobistości spośród delegatów bałkańskich, i strasząc państwa europejskie groźbą inwazji tureckiej, stworzyć potrafił Lord Curzon ${ }^{39}$ zarys Bloku Bałkańskiego, jako przestrogę dla Turków i jako walor do zeskontowania przy dalszych pertraktacjach nad sprawami bezpośrednio Anglię obchodzącymi.

W stosunku do FRANCJI sprawa reparacji była tym punktem, który zabezpieczał Anglii swobodę działania na Konferencji. Jak daleko sięgały wzajemne koncesje, do jakiego stopnia istnieje związek między zamierzoną Konferencją Ekonomiczną a Konferencją Pokojową, nie wiadomo. Stwierdzić jedynie można, że Francji w Lozannie prawie nie ma. Delegacja poza technicznymi ekspertami niemal nie istnieje; jedynymi gospodarzami Konferencji są Anglicy. Lord Curzon przemawia zawsze w imieniu wszystkich aliantów, ambasador Barrère ${ }^{40}$ ogranicza się do aprobowania stanowiska angielskiego. Hamid Beyowi ${ }^{41}$, który jeździł do Poincarégo ${ }^{42}$ o wyjaśnienie stanowiska Francji, oświadczyć miał Premier, że na pomoc Francji Turcja na Konferencji liczyć nie może. Możliwe jest jedynie ciche i nieoficjalne poparcie ich żądań. Niewątpliwe jest, że Francuzi mostów za sobą nie palą i że gen. Weygand ${ }^{43}$, mąż zaufania Poincarégo, przewidziany był na tego, który miał w odpowiedniej chwili podjąć mediację na wypadek, gdyby zaostrzenie się stosunków między Anglią a Turcją groziło zerwaniem Konferencji.

Wpływ WŁOCHÓW nie przejawia się zupełnie. Pochłonięci sprawami wewnętrznymi, kokietujący Turcję i Rosję, nie ujawniają prócz niepoważnych akcji, które miały utrzymać prestige mocarstwowy Włoch, żadnej realnej działalności.

GRECJA roli nie odgrywa. Jedynie autorytet i indywidualność Venizelosa pozwalały początkowo na osobisty jego wpływ w grupie Państw Bałkańskich, zwłaszcza

37 Mudania - port położony nad Morzem Marmara, miejsce zawarcia rozejmu w wojnie grecko-tureckiej 11 października $1922 \mathrm{r}$.

38 Winno być: Wenizelos. Elefterios Wenizelos (1864-1936), polityk grecki, premier rządu w ośmiu gabinetach w latach 1910-1933 (z przerwami).

39 George Nathaniel markiz Curzon of Kedleston (1859-1925), polityk brytyjski, m.in. poseł do Izby Gmin, wicekról Indii, w l. 1919-1924 minister spraw zagranicznych.

40 Camille Barrère (1851-1940), dyplomata francuski, długoletni ambasador w Rzymie (przy Kwirynale, 1897-1924).

41 Hamid Bey (1880-1944), polityk azerski, członek rządu, działacz emigracyjny.

42 Raymond Poincaré (1860-1934), polityk francuski, prezydent Republiki w latach 1913-1920, premier rządu w kilku gabinetach. Podczas Konferencji Lozańskiej na tym stanowisku (od stycznia 1922 do czerwca 1924).

43 Maxime Weygand (1867-1965), generał francuski, wówczas (1923) głównodowodzący sił francuskich na Bliskim Wschodzie i wysoki komisarz francuski w Syrii. 
w granicach potrzeb angielskich. Rozstrzelania Ministrów w Atenach, dalsze wypadki w Grecji, rewelacje wykazujące, że Venizelos był nie mniej ujemnym narzędziem obcych jak Gunaris ${ }^{44}$, oraz ostre scysje delegata greckiego ze Stambulińskim ${ }^{45}$ o Trację Zachodnią ${ }^{46}$, autorytet jego obniżyły. Wpływ Grecji na rokowania jest żaden. Wyzyskany kraj jest w ręku tych, którzy go do ruiny doprowadzili.

DELEGACJA TURECKA mimo silnego b. osłabienia Turcji, mimo b. słabego stanu gospodarczego Anatolii i zmniejszenia ludności o 25\% od roku 1913, przybyła do Lozanny z dużym dorobkiem moralnym. Zwycięstwa armii, poparcie świata muzułmańskiego, nacisk Zgromadzenia Narodowego w Angorze ${ }^{47}$ na nie odstępowanie od zobowiązań przyjętych wobec Narodów w zaprzysiężonym akcie, dają delegacji tureckiej duży autorytet, który spoczywając w ręku Ismeta Paszy, człowieka o nieprzeciętnej sile charakteru, robią stanowisko Turcji silnym.

Tym niemniej znajduje się pierwszy delegat Turcji w położeniu b. trudnym. Demagogia nacjonalistyczna Zgromadzenia Angorskiego i jego krótkowzroczność krępują działalność Ismeta, nie tylko przez ograniczenie pierwotnych pełnomocnictw, ale i przez dodanie do składu delegacji posłów na Zgromadzenie, którzy mają za zadanie równoważenie personalnego wpływu Mustafy Kemala, niezupełnie zgodnego $\mathrm{z}$ tendencjami Zgromadzenia.

Świadomość sytuacji militarnej, która pod względem materialnym, mimo zdobyczy amunicji i artylerii uzyskanej na Grekach, przedstawia się słabo, zmusza tureckie czynniki wojskowe do umiarkowania.

Dowództwo tureckie nie wzięłoby niewątpliwie odpowiedzialności za akcję wojenną przeciw Aliantom, popartą siłami Państw Bałkańskich. Militarny zatem nacisk wywierany przez Anglię, a który znajduje wyraz w tak poważnej koncentracji angielskiej floty w cieśninach, wpływ swój wywiera. Turcy liczyć się muszą również z tym, że przy nowej akcji zbrojnej nie mogliby już otrzymywać pomocy materialnej z Francji. Pozostaje im zatem jedno: odpowiadać naciskiem ze swej strony na presję angielską.

Bluff obustronny odgrywa w całej kampanii niewojennej zupełnie nieprzeciętną rolę z obu stron.

Jako metodę nacisku używał Rząd angorski organizowaną przez siebie akcję powstańczą w Tracji Zachodniej, używa przede wszystkim swej władzy moralnej nad islamem. Formą nacisku jest również sojusz z Rosją sowiecką. Turcja w zasadzie nie ma zaufania do Rosji. Polityka sowiecka w sprawach wschodnich zdradza zbyt

44 Demetrios Gunaris (1867-1922), polityk grecki, m.in. premier i minister spraw wewnętrznych, szef rządu w l. 1921-1922, obalony w następstwie rewolty generałów S. Gontala i N. Plastirasa i rozstrzelany.

45 Aleksander Stambolijski (1879-1923), polityk bułgarski, premier rządu w latach 1919-1923. Zginął w zamachu zaraz po przewrocie ustrojowym w Sofii.

46 Terytorium przypadło Grecji już na mocy postanowień traktatu w Neuilly-sur-Seine.

$47 \mathrm{~W}$ następstwie rewolucji narodowej w Turcji zebrało się Wielkie Zgromadzenie Narodowe w Ankarze, a 29 października 1923 r. proklamowano republikański ustrój państwa. Gen. Kemal został wybrany na urząd Prezydenta Republiki. 
wiele analogii do polityki carskiej. Angora nie może zapomnieć również o 25 milionach mahometan pod panowaniem rosyjskim, którzy w Turcji widzą ostoję ruchu narodowego i religijnego; delegaci Krymu, związku Państw Kaukaskich i Republik Tatarskich, rolę tę przypominają Turcji przez Delegację i emisariuszy. Nie bez obawy patrzą również nacjonaliści tureccy na działalność terrorystyczną kierowaną personalnie przeciw Mustafie Kemalowi, którego bolszewicy uważają za ich zdecydowanego wroga. Zamach na Kemala wykryty w ostatnim miesiącu miał podobno swe źródła w Moskwie. Dzisiejszy stosunek do Rosji jest więc warunkowany i powodowany przede wszystkim koniecznością chwili; tłumaczy się tymi korzyściami, które dawał Turkom podczas wojny i które daje obecnie w czasie Konferencji. Dobre stosunki pomiędzy obu delegacjami są manifestowane. Ostrożność i zapobiegawczość delegacji ma ponadto swoje uzasadnienie w nacisku Zgromadzenia Angorskiego i jego reprezentantów w Lozannie traktujących sojusz z Rządem sowieckim jako wytyczną polityki, której jeszcze nie czas zmienić.

Tej samej taktyki przestrzega na Konferencji Delegacja Rosyjska ${ }^{48}$. Pierwsze jej kroki znamionował brak orientacji. Bolszewicy przypuszczali, że na Konferencji Lozańskiej zastaną Turcję w ścisłej współpracy z Francją. Tym się tłumaczy wystąpienie Worowskiego przypominające historyczne uprawnienia Rosji do cieśnin i sfery wpływów na pograniczu kaukaskim. Rakowski ${ }^{49}$ przyjechał do Lozanny zupełnie niezorientowany. Przekonanie się o izolacji Turcji skłoniło Rosję sowiecką do nawrotu do roli protektorów. Lecz przebieg Konferencji wykazał samodzielność delegacji tureckiej. Indagacje i noty delegacji sowieckiej o charakter jej udziału na Konferencji nie znajdowały poparcia u Turków, którzy na kroki te patrzyli obojętnie. Odrzucenie przez aliantów żądania o dopuszczenie Rosji do całości obrad Konferencji i zagrożenie wstrzymania przyjazdu Cziczerina nie spotkało się w delegacji tureckiej z najmniejszym objawem protestu. W ten sam sposób zachowali się Turcy wobec dalszych not i pretensji rosyjskich. Pomimo więc utrzymywania pozorów trudno było Cziczerinowi zachowywać w Lozannie stanowisko ścisłego sojusznika Turcji. W konsekwencji samodzielności tureckiej przerzuciła się delegacja rosyjska do roli gorliwszych obrońców interesów Turcji i islamu niż „kompromisowa delegacja turecka" prowadzona przez Ismeta Paszę. Wyzyskując nastroje Zgromadzenia Angorskiego i rozgoryczenie części świata mahometańskiego do Turcji, używać zaczęli bolszewicy Konferencję Lozańską jako trybunał wschodniej propagandy. Działalność ich ma obecnie na celu dyskredytowanie Ismeta wobec kraju i podkopywanie autorytetu Turcji w islamie. Prawdopodobne jest, że dla tego samego celu delegacja rosyjska nie podpisze w Lozannie statutu cieśnin, nawet wówczas, gdyby

$48 \mathrm{Na}$ konferencję w Lozannie zaproszono delegację sowiecką, chociaż rząd bolszewickiej Rosji nie brał udziału w Konferencji Pokojowej w Paryżu w roku 1919. Delegacji sowieckiej w Lozannie przewodniczył Cziczerin.

49 Christian Rakowski (1873-1941), polityk i dyplomata sowiecki. Oprócz pobytu w Lozannie sprawował liczne funkcje dyplomatyczne - m.in. był ambasadorem w Paryżu po nawiązaniu stosunków dyplomatycznych ZSRR z Francją w roku 1924. 
go przyjęła delegacja turecka i że uzależni poddanie się „narzuconym” uchwałom od przyjęcia ich przez Zgromadzenie Narodowe w Angorze.

Mimo tego stanu stosunków rosyjsko-tureckich w Lozannie nie ulega wątpliwości, że jak długo pokój nie będzie zawarty, kontakt angorsko-sowiecki będzie utrzymany nawet kosztem ofiar prestige’u i ambicji, który by delegacja turecka musiała ponieść. Taki właśnie fakt miał miejsce przy dyskusji nad cieśninami, kiedy mimo indagacji Curzona, wykazującego, że „Cziczerin przemawia w Fezie”, Ismet nie dał się sprowokować do stwierdzenia różnicy zdań co do tych kwestii między Turcją a Rosją panujących.

Turcja pozostawiona jedynie sobie, nie mając silnych i pewnych sprzymierzeńców, idzie drogą bardzo powolnych koncesji do zdobycia na konferencji realnych podstaw niepodległości państwowej w granicach etnograficznych i w warunkach, które by jej zapewniały pomoc ekonomiczną tych przede wszystkim Państw, których kapitały przedstawiają najmniejsze niebezpieczeństwo polityczne. Powyższymi względami tłumaczy się skłonność Turcji do Kompromisu w stosunku do Anglii.

Racje, które skłaniają Turcję do pełnej ostrożności, są tym większe, że nadzieje w pewnym momencie panujące na realną pomoc Ameryki częściowo zawiodły. Wobec załatwienia kompromisowego kwestii naftowych wprost między konkurentami amerykańsko-angielskimi poza granicami Konferencji, Turcja nie może w sprawie Mosulu ${ }^{50}$ liczyć na poparcie ze strony Ambasadora Childa. Pozostaje więc jedynie powołanie kapitałów amerykańskich do pomocy w odbudowie gospodarczego życia. Zdaje się, że prace w tym kierunku są posunięte dość daleko.

Stosunek Turcji do Polski poza tradycjami i sympatiami historycznymi, do których Turcy przywiązują istotne znaczenie, warunkowany jest w dziedzinie politycznej przede wszystkim stosunkiem Turcji do Rosji. W granicach bieżących zjawisk politycznych, które mogą również wpływać na układ stosunków w przyszłości, odegrać może rolę dzisiejsze stanowisko Rumunii na Konferencji Lozańskiej.

Na ogół rola RUMUNII nie mogła Turcji usposobić korzystnie dla sojusznika Polski.

W obu wypadkach, w których Rumunia, jako zainteresowana zabierała głos, ujawniła się uległość delegacji rumuńskiej względem interesów angielskich. Zwracali na to uwagę Francuzi, na podstawie bezpośrednich obserwacji. To samo wrażenie odnosiło się z oficjalnych wystąpień Ministra Duci ${ }^{51}$ i stosunku jakby „nieczystego sumienia" delegacji rumuńskiej wobec nas.

Zachwyt znalezienia się w orbicie wielkiej jedności wszechalianckiej i pozbycia się jednego z trzech frontów przez wciąganie Bułgarii do bloku europejskiego charakteryzowało pierwszy okres nastrojów delegacji rumuńskiej. Łączył się on z rażącą

50 Spór o Mosul nie został rozwiązany na Konferencji Lozańskiej; będzie zakończony dopiero 5 czerwca 1926 r., kiedy doszedł do skutku układ między Turcją, Irakiem i W. Brytanią o wytyczeniu granicy między Turcją a Irakiem. Mosul przypadł Irakowi.

51 Ion Duca (1879-1933), polityk rumuński, działacz narodowej partii liberalnej, deputowany do parlamentu. 
niechęcią do „wybujałych pretensji” tureckich i podkreśleniem niebezpieczeństwa angorsko-sowieckiego.

Układy Lorda Curzona z Ismetem, w których kompromis miał się dokonać kosztem Państw Bałkańskich, odbiły się echem nieufności do wielkich „wyzyskujących”.

Ale trzeba było już tylko nowej sposobności do nacisku angielskiego, aby delegacja rumuńska zmieniła własną tezę nieścinową ${ }^{52} \mathrm{w}$ sensie, który wprawdzie nie pociąga za sobą w praktyce konsekwencji dla Rumunii ujemnych, ale który niezupełnie pokrywa się z jej interesami. Wysuwanie bowiem projektu demilitaryzacji Morza Czarnego z równoczesnym żądaniem dopuszczenia statków wojennych na to morze, oddaje pobrzeże i handel rumuński w jednostronną zależność Wielkich Mocarstw. W projekcie tym nie widać jasnej i samodzielnej tezy.

O stanowisku Jugosławii i BUŁGARII oraz pobycie Benesza brak dostatecznych danych, trudno więc określić na razie, w jakim układzie wyjdzie Mała Ententa ${ }^{53}$ z Konferencji Lozańskiej. Oderwane fakty wskazują na polepszenie się stosunków wewnętrznych wśród Państw Małej Ententy oraz na to, że Dunaj w nowym układzie stosunków na Bliskim Wschodzie miałby odegrać rolę poważniejszą niż dotychczas.

Z przebiegu dotychczasowego Konferencji okazuje się, że stałej konstelacji Konferencja nie posiada i że wewnątrz naturalnych ugrupowań różnice poglądów wymagają niejednokrotnie daleko idących kompromisów, aby wystąpienia zewnętrzne mogły znaleźć jednolity wyraz.

Bliski i Średni Wschód. Likwidacja frontu Anatolii zmienia b. wyraźnie fizjognomię polityczną Bliskiego Wschodu. Część Państw znika z widowni jako aktywne czynniki życia politycznego, inne znajdą się w odmiennej niż dotąd konstelacji. Niezmieniony zostanie tylko trwały proces rozbudzenia społecznego u milionowych mas, które po raz wtóry przechodzą okres państwowego dojrzewania.

Do Państw schodzących z widowni należy Grecja, a w pewnej mierze także Francja. Francja bowiem poza obroną swego uprzywilejowanego stanowiska patrzeć będzie na Bliski Wschód tylko pod kątem wpływu, jaki mogłaby mieć Turcja na stosunek mahometan Maroka i Algieru do rządów Marszałka Lyouteya ${ }^{54}$.

Głównymi partnerami państwowej polityki na tle zrewolucjonizowanych terenów pozostają: Anglia, Rosja sowiecka i Turcja. Konferencja Lozańska zburzyła racje dotychczasowego ustosunkowania się tych trzech Państw. Teoretycznie są wszystkie kombinacje sojusznicze wśród tych Państw możliwe; każde z nich jest dla dwu innych wrogie, więc zawsze dwa z nich mogą się sprzymierzyć przeciw trzeciemu. Dotąd żadna $\mathrm{z}$ konstelacji nie zarysowała się w sposób, który by pozwalał na wyciąganie wniosków na dalszą przyszłość. Zbyt silnie ciąży jeszcze na wszystkich pań-

52 Tak w tekście. Najpewniej winno być: „cieśninową”.

53 Mała Ententa powstała jako trójstronne ugrupowanie polityczne w latach 1920-1921, skierowane przeciw Węgrom. Łączyła Czechosłowację, Rumunię i Jugosławię. Nie podpisano wówczas jednego aktu założycielskiego, ale tylko porozumienia bilateralne między umawiającymi się stronami.

54 Winno być: Lyauteya. Hubert Lyautey (1854-1934), marszałek Francji, podczas I wojny światowej krótko minister wojny (1917), w latach 1912-1925 rezydent generalny w Maroku (francuskim) i jeden z głównych twórców francuskiego systemu kolonialnego. 
stwach nacisk chwili i interes bezpośrednich sukcesów na Konferencji. W niejednym wystąpieniu delegatów trudno nieraz odróżnić pociągnięcie obliczone na dalszą metę od kroku taktycznego, który ma na celu uzyskanie sukcesu natychmiastowego.

W chwili obecnej zanotować można jedynie tendencje.

W taktyce DELEGACJI TURECKIEJ, zarówno jak w polityce Rządu Angorskiego, przebija zdecydowana chęć zdobycia Turcji najlepszych warunków pokojowego rozwoju. Zdecydowanie zrażona do wszelkich sojuszów i protekcji, po ciężkich doświadczeniach obcych interwencji, liczyć chce tylko na własne siły. W poczuciu słabości i wyczerpania, odrzuca na razie wielkie idee i koncepcje, rezygnuje z wielkich misji i obowiązków. $Z$ tych pobudek płynie w polityce zewnętrznej tendencja do niezrażania sobie zarówno Rosji sowieckiej popieraniem akcji antybolszewickich, jak Anglii forytowaniem ruchów wyzwoleńczych. Stąd wbrew nakłanianiom ze strony Anglii rezerwa w stosunku do delegatów kaukaskich i zrażanie sobie reprezentantów Egiptu, Syrii, Palestyny i Indii niechęcią popierania ich interesów i żądań.

W polityce wewnętrznej wyraziła się ta sama tendencja reformą Kalifatu ${ }^{55}$, wyrzuceniem Patriarchy ${ }^{56}$ i radykalnym wyzbywaniem się mniejszości ze szkodą dla interesów ekonomicznych. Turcja tylko dla Turcji jest niesformułowana, ale realizowanym hasłem rządów obecnych.

Jak długo utrzyma się ta linia polityki, przewidzieć trudno. Stwierdzić można, że nie jest to wyłącznie linia polityki państwowej do momentu zawarcia pokoju, ale jest wyrazem programu politycznego poważnych kół blisko obecnego rządu stojących. Wobec jednak przewidywanych zmian w układzie życia politycznego Turcji po zawarciu pokoju, obecnego kierunku nie można uważać za trwały. Zmiany znaleźć mogą wyraz w przyjęciu szerszych koncepcji i realizowaniu rozleglejszych aspiracji Turcji. Aspiracje te mogą iść w dwóch kierunkach: panturanizmu lub panislamizmu, walki bezpośredniej z Rosją lub pośredniej z Anglią. W ocenie czynników politycznych jest Rosja mniej niebezpieczna jako słaba i w stanie rozkładu; Anglia - wróg groźniejszy. Ten sam mniej więcej sposób załamuje się szeroka opinia publiczna, która oceniając wartość i zyski dotychczasowego sojuszu z Rosją sowiecką, żywi dużą nienawiść do Anglii.

Życie polityczne Turcji wyraża się w poglądach trzech grup. W grupie nacjonalistów, większości dzisiejszego Zgromadzenia Narodowego (Rauf Bey prezes Rządu, Djelal Eddine Arif, poseł w Rzymie), nastrój odpowiadający ogólnej opinii jest wrogi Anglii i poddający się sympatiom rosyjskim; w wojskowej grupie twórców niepodległości tureckiej, jej walk i jej dzisiejszych rządów (Kemal Pasza, Ismet Pasza), jest żywe wyczucie wroga osiągalnego, bezpośredniego i łatwiejszego do pokonania; w grupie ,jedności i postępu”, bardziej konserwatywnej od poprzednich, tendencje są szersze, lecz nieokreślone i niejednolite i nie zamykają się w jednym zdecydowanym kierunku. $\mathrm{Z}$ wyczerpania ogólnego oraz na podstawie wewnętrznych stosunków można przypuszczać, że linia, po której pójdzie polityka turecka,

55 Sułtan był kalifem, czyli zwierzchnikiem religii muzułmańskiej w imperium osmańskim.

56 Mowa o prawosławnym patriarsze ekumenicznym w Konstantynopolu. 
nadana zostanie nie przez ludzi, ale przez życie. Życie zaś postawić może polityce tureckiej jako najbliższe zadanie kwestię Kaukazu.

Dla ROSJI SOWIECKIEJ jest Anglia jednym z głównych przedmiotów ataku, Turcja jednym $z$ najważniejszych obiektów w jej polityce wschodniej.

Z wielkich poczynań Rosji sowieckiej rezultaty jej prac na Wschodzie są niewątpliwie najpoważniejsze. Propaganda, z ogromnym nakładem sił i środków prowadzona, dała na Wschodzie poważne rezultaty. Ta część programu partii komunistycznej, która polegała na obalaniu ustroju kapitalistycznego przez podkopywanie Imperium Brytyjskiego jako jednego z jego filarów, była obmyślana dobrze i życiowo. Autorytet moralny, który ma rząd sowiecki u wszystkich ludów wschodnich walczących z imperializmem brytyjskim, jest największym dorobkiem bolszewików. $Z$ dorobku tego nie mogą zrezygnować nawet za cenę najlepszych stosunków z Anglią. Uznanie zresztą przez Anglię Rosji sowieckiej de jure będzie jedynie wzmocnieniem jej autorytetu na Wschodzie. Według opinii przedstawicieli Wschodu byłoby ono uważane za dowód siły bolszewickiej i zwiększy ciążenie ku Rosji sowieckiej wszystkich wrogów Anglii.

Propaganda uświadomienia narodowego jest jednak równocześnie podgrzebywaniem wielkiej i niepodzielnej Rosji, która jest konieczna dla realizacji całości zamierzeń bolszewickich. W tej sprzeczności tkwi tragizm wielkich placów wschodnich komunizmu. Na terenie najskuteczniejszej swej działalności podkopują własny byt. $\mathrm{Z}$ drogi tej jednak ustąpić nie mogą.

Po likwidacji frontu anatolijskiego przestała Turcja odgrywać dla Rosji sow[ieckiej] rolę ważnego sprzymierzeńca w polityce europejskiej. Możliwość nawiązania przez Turcję stosunków dyplomatycznych z państwami zachodnimi, a przede wszystkim z Polską i Rumunią, oraz jej ewentualne wstąpienie do Ligi Narodów, rolę dotychczasową pod tym względem poważnie zmieniają. Istotne kryterium dla stosunku Rosji sowieckiej względem Turcji stanowi obecnie jej rola w świecie wschodnim. Turcja jako sojusznik państwowej polityki rosyjskiej nie ma ani części tego znaczenia, jakie mogłaby mieć jako sojusznik we wschodnim programie bolszewickim. O tę Turcję walczy jeszcze rząd sowiecki. Dążeniem jego jest, aby na wypadek gdyby się Turcja nie miała stać sprzymierzeńcem Rosji musiała być bezsilna i bez autorytetu w islamie.

Kaukaz, 25 milionów mahometan rosyjskich, cieśniny, tradycje historyczne, a nawet przebieg Konferencji Lozańskiej nie budzą przypuszczalnie w Rosji sow[ieckiej] dużych nadziei na trwałość sojuszu z Turcją.

ANGLIA w rozumieniu niebezpieczeństwa grożącego jej z sojuszu Rosji z Turcją w walce o Wschód rada by wczorajszego wroga zmienić w sprzymierzeńca. Nie bez trudności przychodzi jednak odgrywać Curzonowi rolę obrońcy stanu posiadania i najgroźniejszego przeciwnika delegacji tureckiej, a zarazem twórcy nowego sojuszu przeciw dotychczasowemu sprzymierzeńcowi Turcji. Nie ma danych, które by wskazywały na to, że rząd angielski jest skłonny do wchodzenia równocześnie w bliższe stosunki z Sowietami. W umysłach angielskich żyje raczej koncepcja „kordonu sanitarnego" dokoła Rosji. W kołach ekonomicznych również brak jest 
zaufania do poczynań na terenie Rosji. Zjazd Ogólny przemysłowców naftowych odbyty w Paryżu w połowie grudnia br. zdecydował nieangażować się na terenie Rosji. Ze strony angielskiej poddawano Turkom koncepcję zajęcia Kaukazu i zdradzono wobec nich rzekome oferty bolszewickie do sojuszu przeciw Turkom.

Tendencje angielskie zarysowują się więc dość wyraźnie, wskazując na słuszną ocenę sytuacji z ich strony i niechęć do rezygnowania ze stanu posiadania na Wschodzie.

Powolny jednak, ale stały proces, który się dokonuje na całym obszarze Bliskiego i Średniego Wschodu wskazuje, iż zachwianie się stanu posiadania Anglii na Wschodzie jest rzeczą nieuchronną.

Napięcie tego procesu i rozmiary konsekwencji, które za sobą pociągnie, nie da się ocenić. Stan jego jest jeszcze w fazie narastania świadomości i w stanie tym utrzymywany jest wciąż rozmyślnie przez przywódców do czasu zupełnej dojrzałości. Już dziś jednak objawy jego są b. znamienne.

Najpoważniej przedstawia się działalność rewolucyjna na terenie INDII.

Według słów członka Centralnego Komitetu Rewolucyjnego A. Wahiba ${ }^{57}$ stan ten przedstawia się następująco:

Komitet Rewolucyjny, zdając sobie sprawę z bierności mas i trudności otwartej walki z rządem angielskim, postanowił okres akcji czynnej poprzedzić działalnością zmierzającą do rozbudzenia świadomości niepodległościowej i wrogich nastrojów względem Anglii.

Element najbardziej rozwinięty, wychowany na kulturze europejskiej, zrozumiał, że najkorzystniejsze nawet dla stanu gospodarczego i najliberalniejsze rządy angielskie utrzymywać będą kraj w jednostronnej zależności i prowadzić będą do stworzenia stosunków uniemożliwiających konsolidację i wyzwolenie. Jakby w szerszej skali zapożyczone u bolszewików hasło walki „z chytrością inteligencką wrogą prostocie proletariatu", wyraża się w Indiach poczucie niebezpieczeństwa przed wielką mądrością europejskiej kultury. „Precz ze wszystkim co angielskie” jest naczelnym hasłem wysuniętym przez Gandhiego, wychowanka uniwersytetów angielskich. Bojkot szkół i uniwersytetów, b. zresztą jednostronnych (w uniwersytetach indyjskich chemia jest nauką zakazaną), bojkot towarów angielskich, w pierwszym zaś rzędzie tekstylnych. Do roku 1893 istniał w Indiach zakaz otwierania tkalni. Od czasu Wielkiej Wojny rozwój tkalni idzie w bardzo szybkim tempie, otwierane są wciąż nowe fabryki; a jak oświadczył Wahib, jedna fabryka w Indiach więcej oznacza jedną fabrykę w Anglii mniej. Za 20 lat mają nadzieję osiągnąć w tej dziedzinie samowystarczalność.

Drugą formą walki jest bierny opór wobec zarządzeń władz angielskich. Ruch propagandowy w wielkich miastach spowodował zakaz zgromadzania się. Na miejscach publicznych nie wolno się było pojawiać w grupach większych niż 5 osób. $\mathrm{W}$ odpowiedzi na to zarządzenie wyległ na ulice tłum niedużymi grupami, które

57 Mowa najprawdopodobniej o Indyjskim Komitecie Rewolucyjnym, zorganizowanym w roku 1919 w Berlinie z inspiracji bolszewików rosyjskich. Wahib zajmował się lobowaniem na rzecz jego programu w Europie. 
aresztowano. W więzieniu znalazło się od razu kilka tysięcy biernych demonstrantów. Rodziny zaaresztowanych urządziły weselne uroczystości, aby zaznaczyć radość z powodu tego, że ojcowie, synowie i bracia cierpią dla ojczyzny.

Szkoły, duchowieństwo i organizacje ekonomiczne są środkami stałej i konsekwentnej agitacji.

Podstawowym środkiem propagandy i warunkiem zdobycia autorytetu jest dla ludzi czołowych ich ubóstwo. Działacz społeczny zanim wystąpi wobec mas, składa cały swój majątek na cele publiczne. Brak materialnych zainteresowań jest najsilniejszym argumentem bezinteresowności intencji.

Rezultaty osiągnięte w uświadomieniu mas są podobno znaczne. W większych miastach Anglik ustępuje na drugą stronę ulicy wobec grupy Hindusów. Przejazd następcy tronu angielskiego był tłumną manifestacją wrogości. Persowie, którzy złamali solidarność bojkotu, zostali sterroryzowani szeregiem podpaleń i napadów. Nastrój wrogi względem Anglii jest tak silny, że rozmowa Gandhiego ${ }^{58} \mathrm{z}$ wicekrólem $^{59}$ dała powód do wrogich demonstracji przeciw temu najpopularniejszemu kierownikowi ruchu rewolucyjnego.

Stan walki biernej, której celem jest wzbieranie świadomości mas, ma potrwać jeszcze 2 do 5 lat. Po tym czasie mają się rozpocząć akty terroru w stosunku do cywilnych Anglików, jako pierwszy objaw walki otwartej. Akcja według wzorów Irlandii ma stanowić dalsze stadium walki. Hindusi gotowi są poświęcić walce tej nawet kilka milionów ludzi. „Ginie ich tyleż corocznie z chorób i głodu; przy 330 milionach uszczerbek będzie nieznaczny” - oświadczył Wahib.

Mimo nieufności do Zachodu zdają sobie Hindusi sprawę z konieczności stosunków z Europą. Dążeniem ich jest jednak utrzymywanie stosunków bezpośrednich $\mathrm{z}$ pominięciem Anglii i wyzwolenie się z monopolu angielskiego. Oferty złożone państwom europejskim (między innymi i nam) zostały podobno życzliwie przyjęte przez Włochy i Czechy. Z Beneszem ${ }^{60}$ Wahib rozmawiał osobiście i uzyskał od niego obietnicę zainteresowania się tą sprawą.

Do Japończyków odnoszą się równie nieufnie jak do Anglii, uważając ich za brutalnych egoistów. Jedynym sprzymierzeńcem są do dziś tylko bolszewicy, z którymi pozostają w stałych stosunkach.

Sprzymierzeńcem w walce przeciw Anglii są również państwa objęte mandatami, przede wszystkim zaś Egipt.

EGIPT poddali okupacji Anglicy w 1896 roku, przybywając na wezwanie Kediwa dla stłumienia powstania. Odtąd Anglicy Egiptu już nie opuścili. W chwili przyłączenia się Imperium Ottomańskiego do Państw Centralnych uznana została niezależność Egiptu od protektoratu Sułtana. Pokój Sevrski zmianie tej nadał formę

58 Mahatma Gandhi (1869-1948) - lider założonego przez siebie Indyjskiego Kongresu Narodowego (1921).

59 Wicekrólem Indii był wówczas Earl of Reading (1921-1925).

60 Edvard Beneš (1884-1948), polityk czeski, minister spraw zagranicznych Czechosłowacji w latach 1919-1935. Prezydent Republiki w latach 1935-1938 i następnie na uchodźstwie, jak też po powrocie do kraju (1945-1948). 
prawną, rozciągając natomiast nad Egiptem mandat Ligi Narodów. Jednakże ani zasada mandatu nie została przez Egipt przyjęta, ani sprawowanie mandatu przez Ligę Narodów nie zostało Anglii przekazane. Międzynarodowe stanowisko Egiptu nie jest więc żadnym aktem prawnym unormowane, a obecność i władanie angielskie nie jest również na niczym oparte. W Egipcie panuje chaos. Kediw i Rząd przez Anglię ustanowiony pozbawieni są organów wykonawczych. Administrację sprawuje częściowo armia angielska, częściowo władze niezależne, właściwie zaś nikt. Walki czynnej z okupacją nie ma; prowadzony jest tylko bierny opór, manifestacje i akcja dyplomatyczna za granicą. Ośrodek rewolucyjny stanowi szkolnictwo narodowe, rękami młodzieży dokonywane są akty terroru i manifestacje ${ }^{61}$.

Akcja dyplomatyczna idzie w kierunku wykazania roli, którą Egipt odgrywa w życiu gospodarczym świata, jako klucz do Azji i Afryki, oraz podkreślenia jednostronnych korzyści, które wyciąga bezprawnie Anglia z władania terenem o poważnym znaczeniu międzynarodowym.

O wiele aktywniejszą rolę odgrywają narody walczące o wyzwolenie spod władzy bolszewickiej, a wśród nich najsilniejszy Turkiestan.

Poseł Buchary w Moskwie, orientując hr. Brockdorf Ranzau ${ }^{62}$ o stosunkach w Turkiestanie, określił ludność tamtejszą jako dwie kategorie „bachmadżi” - bachmadżi czynnych, którzy z broną w ręku walczą z bolszewikami, i biernych, którzy im w tej walce pomagają. Motywem tej wrogości do bolszewików jest zarówno charakter rządów sowieckich, który według słów Abdura Barakatuły (Hindusa, jednego z głównych agentów komunistycznych dla wschodnich akcji) jest dużo gorszy od regime’u carskiego, lecz również dzięki rozbudzeniu świadomości narodowej, w czym bolszewicy odegrali b. dodatnią rolę.

Rusyfikacja Turkiestanu przez bolszewików charakteryzuje wzrost Rosjan z 5\% do $15 \%$. Brak zaufania do ludności ze strony rządu sowieckiego znamionuje fakt, że tak jak za carskich czasów ludność miejscowa nie jest powoływana do wojska. Wszyscy Komisarze są ludźmi mianowanymi przez władze centralne; miejscowymi komunistami muzułmanami obsadzane są tylko stanowiska wykonawcze. Reprezentacja ludności w Sowdepach jest minimalna, wobec niższego cenzusu niekwalifikowanych robotników pochodzenia miejscowego.

Wrogość nastroju przeciw bolszewikom stale wzrasta. Nawet Komisarze muzułmanie reagują tylko na krwawe akty przeciw władzy sowieckiej. Redaktorzy miejscowych pism bolszewickich używają prasy sowieckiej dla propagandy niepodległościowej. Pod pretekstem walki z nią drukują i ogłaszają proklamacje i zawiadomienia o rozwoju organizacji. Wzrost siły organizacyjnej i pracy politycznej w ciągu dwóch ubiegłych lat ma być niespodziewanie duży. Siłą rozbudzenia świadomości

61 Jako prowincja imperium tureckiego Egipt w grudniu 1914 r. przeszedł pod protektorat brytyjski. Traktatem z 28 lutego 1922 r. W. Brytania zrzekła się swej dominacji nad tym terytorium, a 15 marca król Faud proklamował niepodległość kraju. Zachowano system kapitulacji, ale Egipt miał własna służbę zagraniczną, a przedstawiciel brytyjski nosił tytuł wysokiego komisarza.

62 Urlich Brockdorf-Rantzau (1869-1928), dyplomata i polityk niemiecki, minister spraw zagranicznych w roku 1919, ambasador w Moskwie w latach 1922-1928. 
w masach porwani zostali przywódcy, którzy do niedawna jeszcze zatrzymywali się na autonomii Turkiestanu. Czugajew ${ }^{63}$, jeden z najwybitniejszych i najbardziej wartościowych działaczy Turkiestanu, delegat autonomicznego rządu turkiestańskiego na pierwszym Uczreditielnoje Sobranie, oświadczył, że w nowym Sobraniu Turkiestan udziału nie weźmie.

Działalność oddziałów powstańczych nie jest traktowana jako droga do obalenia władzy bolszewickiej, ale raczej jako środek propagandy zarówno wobec własnej ludności, jak i wobec bratnich sąsiadów. W braku środków i kierownictwa nie mogą przywódcy liczyć na poważne sukcesy militarne. Te same jednak warunki znakomicie przyczyniają się do moralnego afektu akcji powstańczej. Oddziały powstańcze utrzymywane są w ilości stałego kontyngentu około 50000 ludzi. Kontyngent ten zebrany, jako żywy podatek z góry wyznaczony na pojedyncze osiedla, jest przez nie w miarę spraw uzupełniany. Żywność dostarcza najbliższa ludność. Wobec braku ludzi, którzy przeszli przez wyszkolenie rosyjskie, trudność przedstawiała kwestia dowództwa. Rozwiązano ją zgodnie z tradycjami. Na wodzów oddziałów powstańczych powoływano potomków rodzin mających żywe tradycje powstańcze. Syn lub wnuk bohatera narodowego miał eo ipso tytuł do dowództwa oddziałem powstańczym. Brak tych tradycji rodowych, a przede wszystkim przejęcie władzy z rąk Emira Buchary, niewolonego przez Anglików, uniemożliwiło Enwerowi Paszy ${ }^{64}$ połączenie wszystkich oddziałów powstańczych Turkiestanu i Buchary pod swoim dowództwem i stworzenie wspólnego sztabu.

Zamierzone jest ściągnięcie oddziałów powstańczych w rejon Samarkandy dla umożliwienia współdziałania z powstańcami bucharskimi i dla zbliżenia się ku granicom indyjskim, aby tym ludom wierzącym tylko w to, co sami widzą, dać dowód walki z Rosją sowiecką.

Na wypadek uznania Rosji sowieckiej przez Anglię de jure, przewidywana jest likwidacja czynnej walki z bolszewikami.

PAŃSTWA KAUKASKIE stanowią grupę specjalną zarówno dzięki zróżniczkowanemu charakterowi wewnętrznemu, jak i z powodu specjalnego zainteresowania południowym Kaukazem ze strony wielu czynników zewnętrznych.

Azerbejdżan jako państwo nigdy nie istniał. Drobne nadkaspijskie chanaty zebrane w jeden rejon administracyjny przez rządy carskie zostały po rozpadnięciu się Rosji i powstaniu Gruzji zorganizowane przez turecki Sztab Generalny w samodzielne państwo. Nuri Pasza ${ }^{65}$, organizator tego państwa, zapożyczył nazwę od graniczącej z nim w północnej części Persji. Ludzie do rządów powołani, nieposiada-

63 Pisownia bardziej znana: Czokajew, a właściwie: Mustafa Czokay (1890-1941), działacz turkiestańskiego ruchu narodowego, prezes Tymczasowego Rządu Autonomicznego Turkiestanu, przewodniczący Turkiestańskiego Zjednoczenia Narodowego. Od roku 1921 - przebywał na emigracji (najpierw w Turcji), działał w ruchu prometejskim.

64 Enwer Pasza (1881-1922), generał turecki i polityk, jeden z głównych przywódców rewolucji młodotureckiej $1908 \mathrm{r}$.

65 Nuri Pasza (1837-1900), wódz armii tureckiej podczas wojny z Rosją (1876-1878), dowodził obroną Plewny w latach 1876-1877. 
jący żadnych tradycji państwowych ani poczucia niepodległościowego, podobnie jak ogół ludności, nie umieli niepodległości państwowej obronić przy pierwszym zaraz zagrożeniu. Parlament bez jednego głosu protestu zrzekł się władzy na rzecz bolszewików; bez jednego wystrzału przeszły czerwone wojska przez front armii azerbejdżańskiej i nie odezwał się za granicą żaden głos protestu przedstawicieli tego państwa przeciw inwazji bolszewickiej. Rząd Azerbejdżanu nie zażądał nawet w chwili niebezpieczeństwa interwencji Gruzji, która w myśl konwencji była doń obowiązana.

Dopiero rządy bolszewickie rozpoczęły akcję uświadamiającą jedność państwową i pragnienia niepodległościowe. Rekwizycje i terror dokonały poważnego przeobrażenia umysłowości szerokich mas. Przy ponownej organizacji rządów napotkaliby się Turcy z elementem o wiele podatniejszym i zdolniejszym do państwowego życia.

W GRUZJI świadomość narodowa jest b. silnie rozwinięta i oparta o wspaniałe tradycje. Ludzie, którzy byli u władzy, jak np. Żordanja ${ }^{66}$, to postacie silne o wysoko rozwiniętym poczuciu odpowiedzialności i dumy narodowej. Armia, według opinii b. miarodajnych, okazała się bitna i posiadająca wysokie wartości moralne. Słabością sfer kierowniczych Gruzji była tylko zbyt silna wiara w pomoc z zewnątrz, która ich zupełnie zawiodła.

ARMENIA mimo określonej zupełnie fizjognomii wewnętrznej, zwłaszcza wobec walk religijnych prowadzonych $\mathrm{z}$ mahometanami, jest tworem politycznym bez charakteru.

Wobec dużej różnorodności religii, ras, typów i tradycji trzech państw południowo-kaukaskich, trudno przypuszczać, aby istniała możliwość ich federacji i ścisłej współpracy politycznej. Nawet w dzisiejszym okresie czysto negatywnej działalności wspólność akcji napotyka trudności wobec różnicy sytuacji politycznych. Traktat w Karsie między rządem sowieckim a Angorą, przeprowadzający podział Armenii ${ }^{67}$, spowodował $\mathrm{z}$ inicjatywy emigracyjnego rządu ormiańskiego wspólny protest podpisany w Paryżu przez reprezentantów Państw Kaukaskich. Protest ten stoi obecnie na drodze dobrych stosunków tych państw z Turcją. W silnym również stopniu oddziaływują zaognione stosunki armeńsko-tureckie z powodu zażartych walk religijnych.

Jakakolwiek natomiast akcja na Kaukazie bez poparcia Turcji jest nie do pomyślenia w dzisiejszych warunkach. Liczą się z tym przedstawiciele Gruzji i Azerbejdżanu, zabiegając o stosunki z rządem Angory, zarówno bezpośrednio, jak i za pośrednictwem możnych protektorów. Protektoraty te mogą jednak u Turków raczej utrudnić niż ułatwić stanowisko (szczegółów w tej kwestii jako poufnych nie umieszczam w raporcie).

66 Noe Żordania (1868-1953), polityk gruziński, socjalista, prezydent na uchodźstwie (z siedzibą w Paryżu) po zagarnięciu Gruzji przez sowiecką Rosję w maju 1921 r.

67 Traktat pokojowy turecko-sowiecki podpisano w Kars 13 października 1921 r. i był on dopełnieniem układu obydwu państw z 16 marca 1921 r. (Traktat w Kars ustanowił nowe rozgraniczenie turecko-sowieckie na drodze powrotu do granicy sprzed $1878 \mathrm{r}$. Przeprowadzono więc podział Armenii, z tym że Turcja ustąpiła Sowietom port Batumi, włączony do sowieckiej Gruzji). 
Perspektywy Konferencji. Mimo dużych trudności, z którymi prace posuwają się naprzód, zerwania rokowań przewidywać nie należy. Tym bardziej zaś za zupełnie nieprawdopodobne uważać należy odnowienie akcji wojennej. Dla obu stron prowadzenie działalności wojennej połączone byłoby z bardzo poważnym ryzykiem i wysiłkiem i nie dałoby żadnych pozytywnych rezultatów, nawet dla Anglików, którzy najwięcej mają danych na posługiwanie się argumentem siły. Chęć powrotu z ich strony do traktatu w Sèvres równałaby się zamiarowi cofnięcia czasu. Konsekwencją realną dalszej wojny byłoby tylko zrujnowanie materialne Turcji i kompletne jej wyczerpanie. Taki stan dawałby korzyści bez ryzyka jedynie Rosji sowieckiej i dlatego tylko z jej strony możliwe jest pchanie Turcji na drogę nieustępliwości.

Zerwanie Konferencji bez odnowienia kroków wojennych pociągnęłoby za sobą blokadę Turcji przez państwa europejskie. Ewentualność ta jest już dziś bardzo mało prawdopodobna $\mathrm{z}$ uwagi na duży postęp prac Konferencji i obustronny nastrój kompromisowy.

Charakter źródeł. Powyższa sytuacja przedstawiona została na zasadzie śledzenia przebiegu Konferencji oraz na podstawie szeregu rozmów z nieoficjalnymi przedstawicielami Wschodu, pracującymi za kulisami Konferencji. Kryterium dla otrzymywanych wiadomości stanowiły zatem nie dokumenty, lecz sprawdzanie danych przez zestawianie wiadomości pochodzących z kilku źródeł i ocena wiarygodności osób, od których były otrzymywane.

Schaetzel

mjr Szt. Gen.

\section{Post scriptum}

Polska dyplomacja interesowała się przebiegiem obrad Konferencji Lozańskiej aż do jej końca. Przede wszystkim chodziło o śledzenie rozwoju stosunków tureckorumuńskich. Jak wynika z meldunku attache wojskowego przy Poselstwie Polskim w Bukareszcie (L.252/23 datowanego w Bukareszcie na 5 maja 1923 r.), a zatytułowanego „Stosunki rumuńsko-tureckie i echa z Konferencji Lozańskiej”" ${ }^{8}$, Rumunia, zdając sobie sprawę z możliwości nieporozumień turecko-sowieckich, wykazała duże zainteresowanie zbliżeniem się do Turcji. Zaistniał jednak rumuńsko-turecki spór o wyspę przy rumuńskim brzegu Dunaju - Ada-Kalch.

Rumuni w pierwszej fazie Konferencji - pomimo iż głośno zastrzegali się, iż nie podejmują się żadnego pośrednictwa, daremnie liczyli, że uda im się odegrać rolę cichego pośrednika, świadczącego „bonns office”. Kiedy wszakże spotkał ich zawód - bo nikt o pośrednictwo ich nie poprosił - nastąpiło oziębienie stosunków z Turcją, choć jedynie chwilowo. Celem politycznym Rumunów było oczywiście niedopuszczenie do ponownego zbliżenia bułgarsko-tureckiego. Dyrektor Gabi-

68 Odpis dokumentu przechowywany jest w RGWA w Moskwie (Fond Trofiejny) 308K, opis 9, dzieło 1246, karta 80-80v. 
netu Ministra MSZ Georgescu kilkakrotnie jednak podkreślał w rozmowie z polskim attaché wojskowym konieczność silnego poparcia Turcji z chwilą podpisania traktatu pokojowego w Lozannie.

Licząc na niedochodzenie przez Turcję wątpliwych dawnych tureckich praw do wyspy Ada-Kalch, stanowiącej przed wojną część terytorium Austro-Węgier, rząd Rumunii upoważnił swego Wysokiego Komisarza w Konstantynopolu Filalitiego do zawiadomienia Adnan Beya, że rząd rumuński zgodzi się na uwierzytelnienie Djevad Beya jako ministra pełnomocnego Turcji w Bukareszcie. Oferta została przez Turcję przyjęta. Przybycie Djevad Beya zapowiedziane zostało na drugą połowę maja.

5 maja 1923 r. szef Oddziału II rumuńskiego Sztabu Generalnego oświadczył polskiemu attaché wojskowemu, że stosunki rumuńsko-tureckie będą ,jak przed wojną zupełnie przyjacielskie, lecz o tyle, o ile nie nastąpi zbliżenie turecko-bułgarskie". Niezwykle charakterystyczna jest końcowa uwaga autora raportu (L.252/23): „Obawiałbym się i mam pewne ku temu powody, że nasze przedstawicielstwo w Sofii będzie się starało o wręcz przeciwny cel tj. o zbliżenie bułgarsko-tureckie".

Tak pożądane z punktu widzenia Polski zbliżenie rumuńsko-tureckie o wymowie antysowieckiej ostatecznie nie doszło do skutku. Nastąpi ono dopiero w ramach Ententy Bałkańskiej jako ugrupowania typowo regionalnego.

\section{Turkey in the concepts of the Polish General Staff at the time of the Lausanne Conference (1922-1923) The unknown memorandum of Tadeusz Schaetzel}

The British diplomatic mission, led by lord Curzon, played a central role at the eight-monthslong peace conference in Lausanne (with a temporary breakdown between January and April 1923; the treaty was eventually signed on 24 July 1923), crowned by the achievement of a peace treaty with Turkey. The roles of France and Italy were less significant. Due to a lack of legal title, the U.S. was only granted an observer status. Great Britain's main opponents during the talks, aside from Turkey, were the Soviets, who actively supported the Turkish delegation led by İsmet Paşa (later to become President İsmet İnönü).

Turkey's first demand was the abolition of the capitulation system, which would allow them to come out of the war fully sovereign. The Turkish side also desired to maintain full control over the Straits, and relied on a written authorisation from their National Assembly to break off the negotiations ("National Pact"). The Turkish government also focused on the struggle for an independent state in Anatolia. Eventually, Turkey agreed to honour the debts incurred by the Ottoman Empire, and to allow the demilitarisation of the Straits. They also approved, in a separate convention on the exchange of populations (30 January 1923), the first international agreement on mass resettlement in history.

Józef Piłsudski showed great interest in Turkey's international position and their attitude towards the Soviets, and the authorities in Warsaw saw the Polish-Turkish relations as strategically significant, in accordance with the unwritten doctrine on the importance of coordination between USSR's neighbours in regard to their foreign policies. The role of observer on behalf of the Polish Republic was assumed by Major of the General Staff Tadeusz Schaetzel. He initiated contact with General İsmet via the leader of Crimea Tatars, Djafer Seidamet, a politician professing pro-Polish sympathies who, in 1920, advocated before the League of Nations (in accordance with its Covenant) on the autonomisation of Crimea by means of conferring the mandate for this area onto Poland. On the Polish side, the talks with Turkey were led by Jan Modzelewski, 
Polish Ambassador to the Swiss Confederation and diplomat representing Roman Dmowski's Polish National Committee. The talks brought three agreements signed on 23 July 1923: a treaty on eternal friendship (not an alliance though), and conventions on trade and immigration.

The presented document is of great importance for the analysis of Polish political concepts in relation to the new Kemalist Turkey. The memorandum from 26 December 1922 was written down in Warsaw as an analysis of the first round of negotiations by the emissary of the Polish General Staff, Major Schaetzel, key representative of Polish Promotheism. His hopes remained largely unfulfilled. In consequence of Turkey's conservative policies, the governments in Ankara and Moscow signed a treaty of friendship on 17 December 1925. However, the Polish attempts to spark an international movement of opposition to the Soviet empire on Turkish soil did not prove entirely fruitless. Roman Knoll's mission to Ankara (1924-1925) contributed to the establishment of groundwork for cooperation of emigrants from Promethean nations and the Polish border protection service. In December 1924, the Polish General Staff appointed Tadeusz Schaetzel military attaché to the Embassy in Ankara.

Translated by Jakub Perliński

\section{Турция в концепциях польского Генерального штаба в период Лозаннской конференции (1922-1923). Неизвестный меморандум Тадеуша Шетцеля}

Главную роль во время заседаний 8-месячной мирной конференции в Лозанне (перерыв в заседаниях между январем и апрелем 1923г., договор подписан 24 июля 1923 года) увенчанной подписанием окончательного мира с Турцией, играла британская делегация, которую возглавлял Лорд Керзон. Роль Франции и Италии была менее значимая. Соединенные Штаты, которые не имели юридически обоснованного права участвовать в переговорах, получили в ходе заседаний лишь статус наблюдателя. На конференции главным противником британской делегации, кроме Турции, были приглашенные на заседания представители Советского Союза, активно поддерживающие турецкую делегацию во главе с Исмет-пашей (в дальнейшем президент Исмет Инёню).

Первым требованием Турции была отмена системы капитуляции, тк. она хотела выйти из войны с полным суверенитетом. Следующим - полный контроль над проливами и заранее приготовленное полномочие от Национального собрания разорвать переговоры («Национальный пакт»). Турецкое правительство сосредоточилось также на борьбе за независимое государство в Анатолии. В итоге турецкое правительство согласилось признать османские кредиты, а также демилитаризовать проливы. Оно одобрило, в отдельной конвенции об обмене населением (30 января 1923г.), на первый в истории международный договор, предусматривающий массовые переселения.

Маршал Пилсудский активно интересовался положением Турции и ее политикой по отношению к Советам, а польско-турецкие отношения считались Варшавой стратегически важными согласно неписанной доктрине о потребности в координации политики соседей СССР. Польским наблюдателем, отправленным на Лозаннскую Конференцию был майор Генерального Штаба Тадеуш Шетцель. Он вступил в контакт с ген. Исметом через лидера крымских татар Джафера Сейдамета. Сейдамет был политиком, который представлял пропольское направление и в 1920г. внес идею автономизации Крыма путем выдачи Лигой Нации мандата на эту территорию Польше (согласно Уставу Лигии). С польской стороны польско-турецкими переговорами руководил Ян Модзелевский, посол РП, аккредитованный при правительстве Швейцарской конфедерации и дипломат, связанный с Польским национальным комитетом Дмовского. Переговоры принесли результат - три соглашения, подписанных 23 июля 1923 года: Договор о вечной дружбе (это не был союз), и конвенции - о торговле и переселении. 
Опубликованный документ является важным материалом для анализу польских политических концепций, связанных с новой кемалистской Турцией. Мемориал от 26 декабря 1922г. был написан в Варшаве, как анализ первой части заседаний, работником Генерального штаба майором Шетцелем, выдающимся представителем польского прометеизма. Его надежды в большей мере не сбылись. В результате консерваторской политики Турции 17 декабря 1925 года правительства в Анкаре и Москве подписали договор о дружбе. Польские усилия для создания на территории Турции международного движения по борьбе с советской империей не были совсем тщетными. На территории Турции, в результате миссии Романа Кнолля (1924-1925), были намечены основы для содействия эмиграции прометейских наций и польской дипломатии. В декабре 1924г. Тадеуш Шетцель был отправлен в Анкару польским Генштабом в качестве военного атташе.

Перевод Агнешка Поспишыль

\section{Bibliografia}

Bartoszewicz H., Misja Romana Knolla w Ankarze 1923-1924, „Studia z Dziejów Rosji i Europy Środkowo-Wschodniej", t. 36, 2001.

Batowski H., Między dwiema wojnami 1919-1939. Zarys historii dyplomatycznej, Kraków 1988.

Chmielowska D., Polsko-tureckie stosunki dyplomatyczne w okresie międzywojennym, Warszawa 2006.

Dokument z 1934 r. o zasadach polskiej polityki zagranicznej w Europie Środkowej i na Bałkanach, oprac. J. Tomaszewski, „Przegląd Historyczny”, t. 76, z. 4, 1985.

Documenti per la pace orientale, 1915-1932, ed. A. Giannini, Roma 1933.

Dokumenty z dziejów polskiej polityki zagranicznej 1918-1939, t. 1: 1918-1932, oprac. T. Jędruszczak i M. Nowak-Kiełbikowa, Warszawa 1989.

Hostler Ch. W., Turkism and the Soviets. The Turks of the World and their Political Objective, London 1957.

Kołodziejczyk D., Turcja, Warszawa 2010.

Kornat M., U źródeł idei prometejskiej. Związek Zbliżenia Narodów Odrodzonych (1921-1923), „Nowy Prometeusz”, nr 2, lipiec 2012.

Kozłowski L., Półksiężyc i gwiazda czerwona. Wybór pism, Wilno 1930.

Lewis B., Narodziny nowoczesnej Turcji, przekł. K. Dorosz, Warszawa 1972.

Libicki K., Kaukaz, „Wschód Polski”, nr 5, 1920.

Materski W., Powstanie i upadek państw narodowych na Zakaukaziu (1918-1925), [w:] Państwa narodowe Europy Środkowo-Wschodniej w XX wieku, red. W. Balcerak, Łowicz-Warszawa 2000.

Nevakivi J., Britain, France and the Arab Middle East: 1914-1920, London 1969.

Nicolson H., Curzon: the last phase 1919-1925. A Study in postwar diplomacy, London 1934.

Pod znakiem odpowiedzialności i pracy. Dziesięć wieczorów, Droga, red. A. Skwarczyński, Warszawa 1933.

Sokolnicki M., Polityka Piłsudskiego a Turcja, „Niepodległość”, t. VI, 1958.

Telegrammes de Lusanne. Documents diplomatiques sur la Conférence de la Paix de Lausanne, vol. I, Ankara 1990.

Wituch T., Tureckie przemiany. Dzieje Turcji 1878-1923, Warszawa 1980.

Wroński S., Współdziałanie rządu polskiego z emigracyjnymi organizacjami antyradzieckimi w latach 1918-1939, „Z Dziejów Stosunków Polsko-Radzieckich. Studia i Materiały”, t. III, 1968. 
Joanna Gierowska-Kałłaur, dr hab., prof. IH PAN, wykładowca uniwersytecki SEW UW. Zainteresowania naukowe: historia krajów b. Wielkiego Księstwa Litewskiego w XIX i XX wieku; historia Polski w XX wieku; edycja źródeł. Autorka m.in.: Raporty Straży Kresowej 1919-1920. Ziem Północno-Wschodnich opisanie, seria: „O Niepodległą i granice” VII, Warszawa-Pułtusk 2011 oraz Zarząd Cywilny Ziem Wschodnich (19 lutego 1919-9 września 1920), Warszawa 2003.

Marek Kornat, dr hab., prof. IH PAN, prof. UKSW; historyk i publicysta, kierownik Pracowni Systemów Totalitarnych i Dziejów II Wojny Światowej w Instytucie Historii Polskiej Akademii Nauk w Warszawie. Zainteresowania badawcze: historia dyplomacji i stosunków międzynarodowych w XIX i XX wieku, polska polityka zagraniczna w latach 1918-1945, dzieje polskiej i zachodniej myśli sowietologicznej. Autor m.in.: Polityka zagraniczna Polski 1938-1939. Cztery decyzje Józefa Becka, Muzeum II Wojny Światowej, wyd. Oskar, Gdańsk 2012; Polskie Dokumenty Dyplomatyczne, 1938, PISM, Warszawa 2007. 